\title{
Facebook Digital Marketing: A Thematic Analysis of the Practice of Public Relations Models of Star Hotels in Bandung
}

Received:

24 Juli 2020

Revision

received:

23 Agustus 2020

Accepted:

17 September

2020

\author{
Santosa Sanjaya \\ Jurusan Administrasi Niaga, Politeknik Negeri Bandung, Indonesia
}

\begin{abstract}
:
The purpose of this study is to investigate the Grunig's Public Relations models applied by star-hotels in Bandung through their promotion on Facebook's social media. The thematic analysis was used in this study. The sample of this study included 50 star-hotels in Bandung. All reviews from hotel occupants were checked and coded according to the concerns referred to hotel occupants. Furthermore, all the codes were incorporated into themes that are in accordance with the concepts of the Grunig public relations models. Under certain conditions, all hotels surveyed showed one-way and two-way communication models. For the one-way communication model, some hotels applied press agent/publicity because they did not pay attention to the feedback and reviews from hotel occupants. However, all hotels showed an effort towards the public information model because they disseminated complete information with the support of images relevant to the information disseminated. For the two-way communication model, some hotels applied the two-way asymmetrical model. They responded to criticism from hotel occupants but did not reply directly to the problems raised by hotel occupants. Finally, some hotels applied the two-way symmetrical model because they responded directly to complaints against hotel occupants and promised to improve their services in the future. The sample represents only 50 star-hotels in Bandung, and the study utilizes only qualitative techniques. A similar study using both qualitative and quantitative techniques may generate more insights relating to the Grunig's public relations models applied by star-hotels in Bandung.
\end{abstract}

Keywords: facebook digital marketing, 5 star-hotels, one-way communication model, twoway communication model

\section{Introduction}

In the current digital era, almost half of the earth's population has access to digital communications. Statistics on social media show that in 2019,3.2 billion people on earth use social media to communicate (Tjepkema, 2019). This figure is equal to $42 \%$ of the earth's population today. This picture has caused social media like Facebook to become highly effective digital promotional media for companies that want to maintain a positive corporate image and at the same time, increase sales of their products and services. Facebook was chosen because Facebook is still the most widely used social media in Indonesia (Nancy, 2019). In addition, 82 percent of Facebook users consist of the age group between 18 and 54 years who are still actively traveling (napoleoncat.com, 2020).

Currently, star hotels in Bandung use Facebook social media to promote their products and services. The contents of the fan pages of these hotels offer hotel facilities such as free breakfast, room service, meeting rooms, weddings and events, money changer, free parking, restaurant/bar, free wi-fi, swimming 
pool, and so on. This online communication is one of the public relations activities where the public can find out what are offered by five-star hotels in Bandung. Based on four models of public relations (Grunig and Hunt, 1984), what models did the hotel apply in promoting their products and services? This study aims to investigate the models of public relations adopted by five-star hotels in Bandung in promoting their products and services. The benefits of this study are to provide input to hotel managers about the public model desired by hotel occupants and to enrich the literature on public relations models in hotels.

\section{Literature Review}

Digital marketing in Indonesia is very promising. This condition is supported by the fact that social media users, especially the number of Facebook users in Indonesia. According to Statista Research Department (2019), in July 2019, there were more than 120 million Facebook users in Indonesia. In other words, with the population of Indonesia in August 2019 of 270 million people (World Population Review, August 2019), more than 44\% of the Indonesian population uses Facebook.

\section{Social Media and Digital Marketing}

Digital marketing is inevitable in 2019. Humans are currently interacting and deciding to travel through smartphones, social media channels, and email. (SiteMinder, 2019). Tourists now like to write their travel experiences on social media channels, so hotel management opens digital communication channels on their social media accounts (hotelSpeak, 2017).

HotelSpeak (2017) further explained that Facebook is still an important social media marketing channel for hotels. Similarly, Mitch and Baggio (2015) emphasize that social media websites have an increasingly important role in hotel promotion and marketing. Then, what causes the role of hotel promotions through social media to increase?

The development of social media such as Facebook with high connectivity and interactivity has led many public relations practitioners to use this media effectively (Lee and Low, 2013). Facebook has replaced the role of public relations practitioners in conveying information to the public. For example, many hotels promote hotel rates via Facebook (Gulbahar \& Yildirin, 2015). Overall, hotel management such as hotel marketing managers can facilitate public curiosity by obtaining and exchanging information via Facebook (Abuhashesh et al, 2019).

The role of digital promotion by hotels is increasing because of changes in attitudes and behavior of consumers when choosing tourist sites and accommodation, deciding to buy, and telling their experiences through social media. Mitch and Baggio (2015) and Smith (2018) found that tourists now rely on the comments and reviews of social media users before they choose and book hotel accommodations. Gascon et al. (2016) revealed, online, the majority of tourists read consumer comments before they plan their tour. Smith (2018) emphasizes that social media provides opportunities for hotels to build guest relationships and strengthen hotel reputation online. Therefore, making social media channels a crucial hotel marketing tool (Smith, 2018) because social media has been transformed into an innovative tool where hotel management will be able to manage brand relationships with its consumers by analyzing consumer posts on social media (Al-Msallam \& Alhaddad, 2016).

\section{Difference Between Advertising and Public Relations}

The question that may arise is, "Are the hotel platforms depicted on Facebook part of the advertising or public relations?" Advertising and Public relations are two very important communication tools to promote products and services offered by companies (Surbhi, 2017). Surbhi further explained that advertising refers to a form of corporate communication aimed at prospective customers for a product offered by the company. Conversely, public relations refer to building and maintaining good relationships with company stakeholders by trying to obtain the desired qualities of the company and having a good reputation in the public eye. In other words, public relations is the process of developing a positive image of the company in the minds of the public in general (Joseph, 2019).

Facebook has evolved into a real public relations instrument (Johnson, 2019). This argument is consistent with two characteristics of advertising (Pahwa, 2019) that are less compatible with Facebook characteristics, (1) paid form, and (2) one-way communication. According to Johnson 
(2019) Facebook is a non-paid communication media. The only cost we have to spend is the time you spend posting information, monitoring public responses, and posting replies. It can be concluded that because Facebook is not paid and provides broad space for organizations and their public to conduct two-way communication, the information provided by the organization to its public is an effort of Public relations.

The overall efforts of public relations practitioners have been transformed from traditional styles to more innovative styles using social media (Rousseau \& Puttaraju, 2014) which provide ample scope to promote business, post special offers, and build relationships with the public such as the media and consumers (Johnson, 2019). Social media such as Twitter and Facebook are examples of good platforms for companies to communicate and achieve shared types of public and update all information to the public above (Vaughan, 2019). Facebook and other social media channels can be an important part of your PR strategy. It can also be a massive waste of time and energy if not well managed. With clear goals, good measurement tools, and a focus on quality and responsiveness, you can make the most of your Facebook community (Bergen, 2015). Public relations and social media are both about creating and fostering relationships (Rousseau \& Puttaraju, 2014).

\section{Public Relations Models}

In 1984, Grunig and Hunt developed four models of public relations, commonly called 'the four models of public relations' (Borgman, 2016). These four models consist of Press agent, Public information, Two-Way Asymmetrical Model, and Two-Way Symmetrical Model. Stračiak \& Šindleryová (2015) consider that Grunig and Hunt have made the biggest and most valuable contribution to the formation of a public relations model. Joseph (2017) argues that Grunig's research on these four models of public relations has added many theories to the existing "body of knowledge." Still according to Joseph (2017) this theory has helped develop the field of public relations in many ways. Public relations practitioner. Stračiak \& Šindleryová (2015) argue that this model disseminates "theoretical knowledge of universities" and that in the future, it must be an educational material about relations with the public.

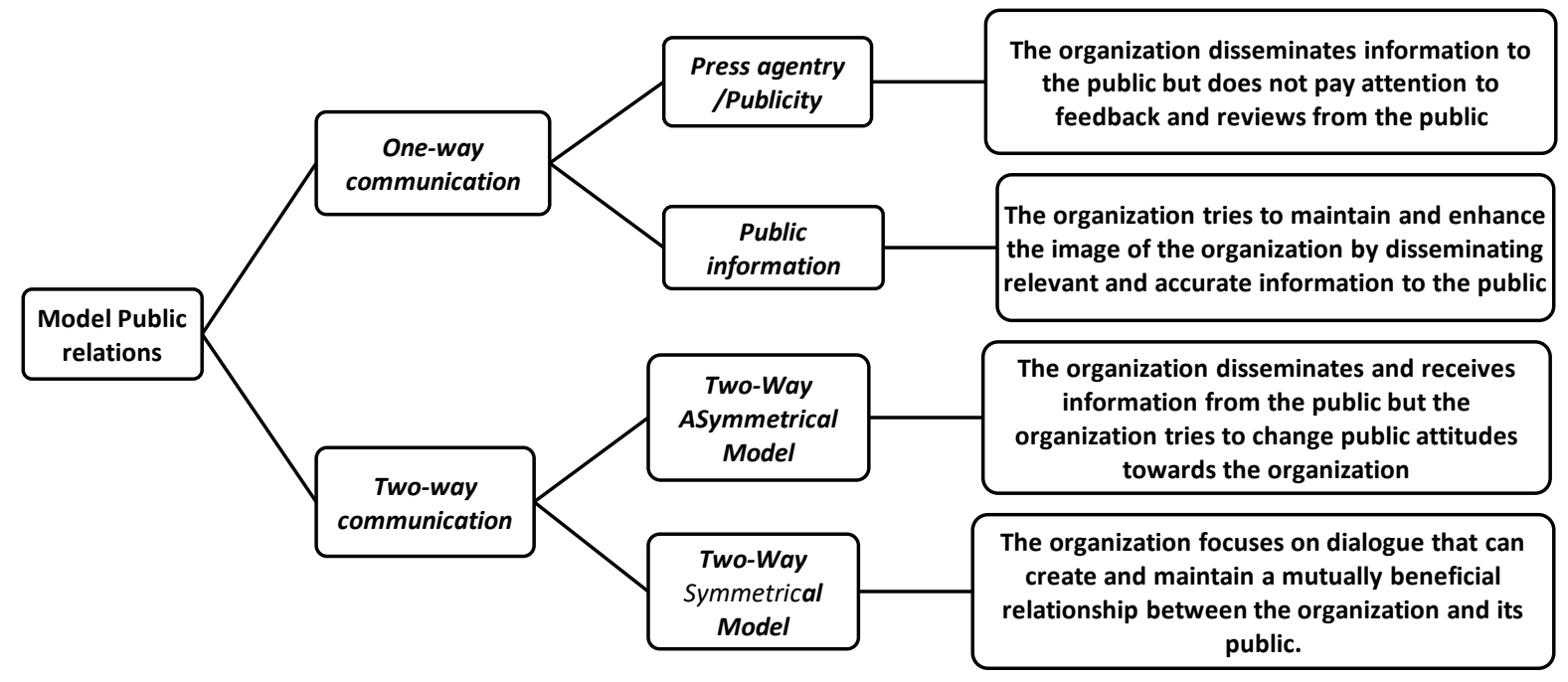

Figure 1 The Four Models of Grunig's Public relations

From the form of communication, the four models of public relations are divided into one-way communication models and two-way communication models. Dlamini (2016) considers that Grunig and Hunt describe the press agentry and the public information as forms of one-way communication while Symmetrical models and Asymmetrical models are forms of two-way communication. Tewes (2016) explains the press agency model and the public information model is a form of one-way communication because information only flows in one direction, from the organization to the public and research on stakeholders and what their interests and concerns are not carried out. Dialogue between the organization and stakeholders does not occur. In contrast, the two-way Asymmetrical model and the Symmetrical two-way model emphasize the occurrence of two-way communication. 
The organization that applies these two models creates a communication channel that enables the exchange of information between the organization and its public.

\section{The Press Agentry Model}

The Press Agentry Model is a one-way communication model from the organization to the public by means of persuasion and manipulation to influence public behavior (Simpson, 2014). Information in this model only moves from the organization to the public. Dlamini (2016) calls this model a "sourceto-receiver" communication model. This communication model emphasizes publication for the benefit of the organization while information accuracy is not considered important for the organization (Tewes, 2016). In other words, organizations control the communication channel and information content (Taylor \& Kent, 2014).

In the Press agentry model, the organization communicates to the public for the benefit of the organization so that the company's corporate image will be well maintained. The organization tries to make its public aware of the company's corporate social responsibility (CSR) projects in the public community (Dlamini, 2016). The aim is to make the public aware that the organization has carried out activities that help the community. In some cases, the model communication method is adopted by public relations practitioners to sell products or services without any attempt to conduct a quantitative analysis of the results of the sale of the product or service (Simpson, 2014). One of the characteristics of the press agentry model is that organizations do not pay attention to feedback and reviews from the public (Ukessays, 2019; Seletzky and Lehman-Wilzig, 2010; and Beverly, 2013).

\section{Public Information Model}

The public information model still reflects the form of one-way communication, but the accuracy of messages becomes more vital (Simpson, 2014). Borgman (2016) considers this model to provide objective information through various mass media. This model of public relations practitioners provides accurate information that is generally preferred by organizations, but research is not carried out (Tewes, 2016). Although this model does not make a qualitative analysis of the results, these practitioners are a little more interested in gathering feedback from the public (Simpson, 2014).

The Public information model does not consider information about its public to be important in shaping messages and press releases (Simpson, 2014). Therefore, this model is used by organizations to publicize organizational interests, such as corporate social responsibility activities in their public environment (Dlamini, 2016). This model is mostly applied by government agencies, military units, and legal agencies (Simpson, 2014). Whereas Tewes (2016) assesses universities and government offices often use this model, disseminating information through brochures, press releases, and websites that describe aspects of the interests of these organizations (Tewes, 2016).

\section{The Two-Way Asymmetrical Model}

In the asymmetrical two-way model, feedback is considered important for public relations practitioners, but the aim is not to improve organizational practice, but to influence public attitudes (Simpson, 2014). This model uses an unbalanced approach that uses research results to create the best messages to persuade and influence the public to behave in accordance with organizational interests (Tewes, 2016) According to Dlamini (2016) and (Turney, 2017) this model is often referred to as a 'scientific persuasion' model and the majority were developed based on information and propaganda (Dlamini, 2016). Furthermore, Turney (2017) described this model as a model that adopted the method of "social science" to develop persuasive communication.

In a nutshell, Turney (2017) described the Asymmetric two-way model generally focused on changing public attitudes in the short term (short-term attitude change). According to Tewes (2016), this model is clearly illustrated in advertising and marketing, where public relations practitioners look for information that will create added value and build brand equity. In other words, this model is applied by organizations to persuade the public to accept organizational decisions or views (Dlamini, 2016). From this presentation it is clear that this model is used primarily by organizations that are interested in getting their public to behave in accordance with the interests of the organization compared to efforts to change policies and organizational views in accordance with public attitudes (Turney, 2017). 


\section{Two-Way Symmetrical Model}

The two-way symmetrical model facilitates mutual understanding and mutual respect between the organization and its public (Dlamini, 2016). This model provides an opportunity for organizations to listen to the interests and concerns of stakeholders and negotiate for the interests of both parties through media or personal interaction (Tewes, 2016). Turney (2017) further illustrates this model relying on open and honest communication in both directions and focusing on mutual respect and efforts to achieve mutual understanding, emphasizing negotiation and a willingness to adapt and make compromises (Turney 2017). Because this model emphasizes honest, objective, and open two-way communication, Borgman (2016) argues that the practice of the public relations model is a strong foundation for "customer trust and loyalty".

Customer trust and loyalty reflect that this Symmetric two-way model is the most ethical public relations practice because it balances the interests and needs of the organization and its public (Borgman, 2016). Simpson (2014), Dlamini (2016) and Tewes (2016) reinforce Borgman's (2016) argument that the model is the most ethical because this model promotes dialogue between the two parties. In summary, this model becomes a very ethical model because the organization does not act as a decision-maker but rather functions as a mediator (Dlamini, 2016; Tewes, 2016), facilitates trust, transparency and accountability (Dlamini, 2016) and feedback is gathered by the organization to change organizational practices (Simpson, 2014).

\section{Recent Research Results}

Recent research results on the public relations model show that organizations are currently applying the two-way communication model, but they prefer the Asymmetric two-way model. Turney (2017) cites Grunig's research findings that the current model of public relations that is the most effective and most sought after by public relations practitioners is the two-way Asymmetric model compared to the Symmetric two-way model. Dlamini (2016) in his study found that companies in Richards Bay, South Africa tended to use a combined two-way Asymmetric and two-way Symmetric model. Research conducted by Tewes (2016) shows that professional organizations in the field of sports prefer two-way Asymmetric because the practitioners' model is able to use research results to persuade and influence the public to behave in accordance with organizational interests. Finally, Krisyantono et al. (2017) found in his research in Indonesia that public relations practitioners both government agencies and private businesses implemented models of two-way communication. These organizations implement both Asymmetric and Symmetric. However, public relations practitioners of government agencies are more likely to use the Asymmetric two-way communication model.

\section{Method}

Bandung has 118 star hotels (data.bandung.go.id, 2018)and 50 of them were used in this study. According to Gentles et al. (2015) for the qualitative research sample size varied from 6 to 30 participants/source or more. Therefore, a sample size of 50 is sufficient for this study. In this study, the fifty hotels were surveyed through the Facebook social media they manage. The survey was conducted on reviews of hotel occupants from 2 August 2019 to 8 October 2019. The details of the hotels are as follows:

Table 1. Classification and Number of Hotels Surveyed

\begin{tabular}{ccc}
\hline No & Classification & Number of Hotel(s) \\
\hline 1 & 1 star & 1 \\
2 & 2 star & 7 \\
3 & 3 star & 17 \\
4 & 4 star & 20 \\
5 & 5 star & 5 \\
\hline
\end{tabular}


Purposive sampling was used in this study to be able to dig deeper information (Patton, 2015). Star hotels in Bandung where their social media Facebook gets a lot of comments from the hotel occupants chosen to be the sample of this study. The selection of these hotels was made with the consideration that the more comments were given by hotel occupants, the more information will be obtained about the quality of their services. With the amount of information obtained, there will be more themes to be studied more deeply.

Why should these themes be studied more deeply? This is because hotel management will find it easier to learn about their shortcomings. Social media has the ability to deliver content and feedback quickly, efficiently and in real time (Hudson, 2020). Therefore, providing a review page on Facebook will increase the number of consumers to rate your business (reviewtrackers.com, 2020). In an industrial hotel environment, the more reviews are written, the more management will know what is wrong and right in managing their business and stimulate management to make more improvements.

The data processing in this study uses a thematic analysis. Thematic analysis is a good approach for examining people's views, opinions, knowledge, experience or values from a collection of qualitative data such as interview transcripts and social media profiles (Caulfield, 2019). Still, according to Caulfield, the steps in implementing thematic analysis are as follows: (1) familiarization; (2) coding; (3) generating themes; (4) reviewing themes; (5) defining and naming themes; and (6) writing up. In order to be familiar with the context, reading all comments from hotel occupants were made. Highlighting of phrases or sentences that have the same idea is done in the coding step. In the steps of generating themes, the codes that have the same ideas are then included in narrower themes. Next, the themes are reviewed in the reviewing themes step. After that the themes are named according to this research namely public relations models. The final step is writing an analysis of the data that has been collected.

\section{Results and Discussion}

Digital promotions of fifty star-hotels in Bandung were surveyed through hotel occupant reviews on the Facebook fan pages. The survey results show that the hotels surveyed did not only apply one model of public relations. In certain conditions, these hotels use only one-way communication models. However, at certain moments, they apply the two-way communication model. In essence, the hotels surveyed, under certain conditions, applied the press agentry model, the public information model, the two-way-asymmetric model and, the two-way symmetric model.

\section{Press Agentry Model}

Hotel occupants like to give comments about the hotel facilities they inhabit. These comments can be either praise or criticism. However, 12 hotels in Bandung do not always pay attention and provide feedback on praise and criticism of hotel occupants. They just let the praise or criticism addressed to their hotel through the reviews available on Facebook Fan pages. This condition reflects one of the characteristics of the press agent model in which the organization does not pay attention to public feedback.

Table 2. Number of Compliments and Criticism from Hotel Occupants

\begin{tabular}{ccccc}
\hline Compliments & Total & Criticism & Total & $\begin{array}{c}\text { Feedback to Hotel } \\
\text { Occupants }\end{array}$ \\
\hline strategic place & 20 & food & 7 & 27 From 50 Hotels \\
price & 7 & service & 5 & \\
facility & 12 & cleanliness/comfortable & 9 & \\
food & 28 & facilities & 19 & \\
comfortable/cleanliness & 39 & Price & 1 & \\
scenery & 7 & & & \\
service & 37 & & &
\end{tabular}

The press agent model tries to change public behaviour without any organizational effort to change their own behaviour. This model uses various methods to publicize its organization through the media. 
Grunig \& Hunt (1984) confirm that this model illustrates the propaganda function. Star hotels in Bandung do not appear to be making any propaganda effort or trying to change the public's view of their hotels. However, from the reviews given by hotel occupants, it appears that hotel management sometimes does not care or does not respond to comments made by hotel occupants. One of the characteristics of the press agentry model is that organizations do not pay attention to feedback and reviews from the public (ukessays, 2019; Seletzky and Lehman-Wilzig, 2010; and Beverly, 2013).

Table 3. Compliments and Criticism from Hotel Occupants

\begin{tabular}{|c|c|c|}
\hline Compliment Review & Criticism Review & Feedback From Hotel \\
\hline $\begin{array}{l}\text { Good view, very friendly, good } \\
\text { menu, okay service (OC1); } \\
\text { Everything is good, food and } \\
\text { everything is great (OC2); A } \\
\text { unique hotel that is amazing and } \\
\text { my family really likes it. This is a } \\
\text { precious moment for us to spend } \\
\text { the night there (OC3) }\end{array}$ & $\begin{array}{l}\text { I suggest [your hotel] make } \\
\text { a member card with points } \\
\text { and discounts for fanatical } \\
\text { customers like me and my } \\
\text { family (OC1) }\end{array}$ & \\
\hline $\begin{array}{l}\text { Beautiful sunrise view, unique } \\
\text { designs, fresh and delicious food, } \\
\text { high qualified furniture, friendly } \\
\text { staff (OC4); It's fun, the food is also } \\
\text { delicious (OC5). I recommend that } \\
\text { the Meeting Room be tried by other } \\
\text { corporations, because I really enjoy } \\
\text { it. Thank you (OC6) }\end{array}$ & & \\
\hline $\begin{array}{l}\text { exceptional hospitality by the staff } \\
\text { there. Courteous and helpful. } \\
\text { Highly personalized experience } \\
\text { (OC7); For a varied breakfast } \\
\text { menu, room-friendly service is not } \\
\text { bad ... But overall good (OC8); The } \\
\text { service is friendly ... the breakfast } \\
\text { is really good, clean and fresh food, } \\
\text { the room is spacious, clean, and } \\
\text { very cozy ... the pool is also } \\
\text { spacious ... Recommended for } \\
\text { families who want a vacation } \\
\text { because it's so close to Ciwalk. } \\
\text { access is also easy because the } \\
\text { place is very strategic (OC9) }\end{array}$ & $\begin{array}{l}\text { But, to check in to the } \\
\text { room, we had to wait a bit } \\
\text { longer ... Even though I } \\
\text { checked in already after } 7 \\
\text { pm, but still we had to wait } \\
\text { a bit longer (OC7) }\end{array}$ & \\
\hline
\end{tabular}

From table 2 and table 3, it can be seen that of the fifty hotels surveyed, only twenty-seven hotels provided feedback on hotel occupants' reviews. Twenty-three hotels surveyed did not provide feedback on praise or criticism delivered by the hotel occupants. The hotel management is not interested in expressing gratitude for the compliments of the hotel occupants or for clarifying the criticisms of the hotel occupants. This picture is consistent with the characteristics of the press agentry model described by UKessays (2019); Seletzky and Lehman-Wilzig (2010); and Beverly, 2013).

\section{Public Information Model}

Digital promotion efforts carried out by hotels at this time, under certain conditions, illustrate the existence of a public information model. The description of their hotels is displayed in the form of text, 
photos, and videos. This, in one sense, illustrates one-way communication. On the other hand, it is illustrated that this promotional effort was carried out verbally and visually. Verbal images are reinforced by the presence of photographs and videos so that the facilities and services provided by the hotel appear to be more accurate and objective (Simpson, 2014 and Borgman 2016). These conditions are reflected in the fifty star-hotels surveyed.

Table 4. Types of Products and Service in Star Hotels

\begin{tabular}{clc}
\hline No & \multicolumn{1}{c}{ Products/Service } & Number of Hotel \\
\hline 1 & Free breakfast & 42 \\
2 & Room service & 50 \\
3 & Meeting room & 42 \\
4 & Wedding and event & 35 \\
5 & Gathering & 23 \\
6 & Laundry & 42 \\
7 & Massage service & 9 \\
8 & Spa & 22 \\
9 & Fitness & 17 \\
10 & Photocopy service & 1 \\
11 & Transport rental services & 23 \\
12 & Karaoke & 2 \\
13 & Concierge service & 8 \\
14 & Money changer & 1 \\
15 & Free parking & 24 \\
16 & Restaurant / bar & 25 \\
17 & Free Wi-fi & 50 \\
18 & Swimming pool & 28 \\
\hline
\end{tabular}

As seen in table 4, star hotels in Bandung offer various types of products and services to potential customers. These products and services are not only displayed in writing but are strengthened by the presence of photographs and videos. With images and videos, it is hoped that consumers will become increasingly confident in the products and services offered. This description is consistent with one of the characteristics of the public information model, where information provided by organizations to the public must be objective and accurate (Simpson, 2014 and Borgman 2016). The products and services offered will become increasingly objective and accurate with the support of photographs and videovideos. The swimming pool and laundry offered will be more apparent if there are photographs. Videos will also show conditions that are more objective and accurate on the products offered.

\section{Two-way Asymmetrical Model}

Hotel occupants usually like to write complaints in the Facebook review section if they feel the services or facilities provided are not in line with their expectations. Hotel facilities such as hotel rooms, bathrooms, furniture, places of worship, swimming pools, until food will usually be the object they value. The hotel occupants hope that these complaints are met properly and there is an effort or at least there is a promise from the hotel management to improve its services. With the response from the hotel management, the hotel occupants will feel satisfied or at least feel valued because their concerns are considered by the hotel management.

Table 5. Responds from Hotel Management

\section{Complaints of the Hotel Occupants \\ Answers from Hotel Management}

the bathroom smells, maybe the smell comes from the sanitary channel (OC10)
Thank you for taking the time to leave a rating and review for $\{\mathrm{X}$ Hotel $\}$, Bandung! We are happy to hear that you find the service we provide satisfactorily. We hope you will be willing to visit [X Hotel], Bandung again. 
but, just a suggestion, for such a large and good hotel, please expand the Mushola or if possible, it should be separated from other buildings, thanks (OC11)

... only the swimming pool is rather small... (OC12)
Thank you for warm greeting about [Y Hotel]. We hope you choose to create more memories with us whenever your travel brings you back to Bandung.

Thank you, we are waiting for your return

In fact, complaints from hotel occupants are not always responded to properly. 17 hotels did not directly answer complaints made by the hotel occupants. They also did not apologize for the lack of servants provided by hotel management. The hotel management prefers to express their gratitude for the arrival of hotel guests and promote the positive sides of their service to the hotel occupants.

One characteristic of the two-way asymmetrical model is that organizations try to make their public behave in accordance with organizational interests (Turney, 2017). In table 4, it is illustrated that the organizations try to divert attention from complaints submitted by hotel occupants to services and facilities that are deemed to have satisfied their customers. Hotel management is not interested in reviewing consumer complaints, but rather interested in promoting the positive aspects of their hotels.

\section{Two-way Symmetrical Model}

The Two-way Symmetrical Model is based on two-way communication and involves mutual reciprocal interaction between an organization and its public. One feature of this model is that organizations pay attention to and respond well to complaints from the public. With a good response from the organization, the public will feel happy and their interests are taken care of and valued.

The study reveals that only 10 hotels in Bandung respond to the complaints of the hotel occupants by expressing their gratitude for their input. Sometimes hotel management also starts responding by apologizing for the lack of service received by hotel occupants. The next stage, hotel management promised to correct their mistakes and would try to improve their services in the future. This condition is in accordance with the characteristics of the Symmetrical Two-way Public Relations model presented by Tewes (2016) where the model provides an opportunity for organizations to listen to the interests and concerns of stakeholders and negotiates for the interests of both parties through media or personal interaction.

Table 6. Reciprocal Responds from Hotel Management

\begin{tabular}{|c|c|}
\hline Complaints of the Hotel Occupants & Answers from Hotel Management \\
\hline $\begin{array}{c}\ldots \text { but the room is rather small }(\mathrm{OC} 13) ; \ldots . \mathrm{WI}- \\
\text { FI not good. There is no wardrobe to store } \\
\text { clothes }(\mathrm{OC} 14)\end{array}$ & $\begin{array}{c}\text { Wow, very happy;) Thank you for staying at [X } \\
\text { Hotel], Bandung, we will wait for your return next } \\
\text { time:) ... we will improve our service and [thank } \\
\text { you for] your input. }\end{array}$ \\
\hline $\begin{array}{l}\text { Please expand the swimming pool, for the } \\
\text { adults (OC15) }\end{array}$ & $\begin{array}{c}\text { thank you for visiting, sorry if there is a lack of } \\
\text { service }\end{array}$ \\
\hline $\begin{array}{c}\ldots \text { only the bathroom was not clean enough and } \\
\text { there wasn't a thermos of hot water, tea, sugar } \\
\text { and coffee (OC16) }\end{array}$ & sorry, we will resolve it later \\
\hline $\begin{array}{l}\text {... but the seat is not good, if possible, please } \\
\text { repair it with the backrest (OC17) }\end{array}$ & $\begin{array}{l}\text { Thank you Mr. }(\mathrm{OC} 17) \text { for the review. Sorry, do } \\
\text { you mean which seat in the area is uncomfortable, } \\
\text { sir? so we can fix it right away. thank you }\end{array}$ \\
\hline $\begin{array}{l}\text { spacious room although the shower room is } \\
\text { quite small (OC18) }\end{array}$ & $\begin{array}{l}\text { Thank you for leaving feedback via Facebook. We } \\
\text { will try to maximize our services in the future. We } \\
\text { look forward to welcoming you back to [Z Hotel], } \\
\text { Bandung }\end{array}$ \\
\hline
\end{tabular}


As illustrated in table 6, hotel management gives positive feedback on complaints submitted by hotel occupants. They expressed their gratitude for the reviews that had been given. They also greeted the apology for the lack of servants that had been given. Even more important is that they promise to correct mistakes in checking and improve service in the future. This picture is consistent with the argument of Simpson (2014) in which the two-way symmetrical model puts forward two-way communication and the promise of organizations to change their practices according to the wishes of the public.

\section{Conclusions}

Star hotels in Bandung do not apply only one model of public relations introduced by Grunig and Hunt. These hotels apply the public relations model according to the conditions and facilities that they have. Sometimes they do not respond to the complaints of hotel residents because they do not have the facilities that hotel residents complained about. Under certain conditions, all hotels surveyed show a one-way and two-way communication model. For the one-way communication model, 12 hotels apply press / publicity agents because they don't pay attention to feedback and reviews from hotel occupants. However, all hotels show efforts towards the public information model because they disseminate complete information with the support of images that are relevant to the information disseminated. For the two-way communication model, 17 hotels adopt a two-way asymmetric model. They responded to criticism from hotel occupants but did not directly answer the problems raised by hotel occupants. Finally, 10 hotels adopt a two-way symmetrical model because they respond immediately to complaints against hotel occupants and promise to improve their services in the future.

\section{References}

Abuhashesh, Mohammd; Al-Khasawneh, Mohammad; Al-Dmour, Masa'deh, Rand; Ra'ed (2019). The Impact of Facebook on Jordanian Consumers' Decision Process in the Hotel Selection. IBIMA Business Review, Vol. 2019 (2019), Article ID 928418, DOI: 10.5171/2019.928418

Al-Msallam, Samaan \& Alhaddad, Abdullah (July. 2016). The Effects of Social Media Marketing In the Hotel Industry: Conceptual Model for Development of an Effective Online Community. International Journal of Business and Management Invention. 5 (7), 01-12

Bergen, Max (December 2, 2015). 10 Tips for Using Facebook for Public relations. Available at https://blog.trendkite.com/trendkite-blog/10-tips-for-using-Facebook-for-public-relations

Beverly, Jason Antwuan (2013). Public Relations Models and Dialogic Communication in the Twitterverse: An Analysis of How Colleges and Universities are Engaging Their Publics Through Twitter" (2013). Dissertations. 159. https://aquila.usm.edu/dissertations/159

Borgman, Monica (April 26, 2016) Comparative success of Grunig and Hunt's four models of public relations practice. Available at https://mishapsandponderingsofa20something. wordpress.com/2016/04/26/comparative-success-of-grunig-and-hunts-four-models-of-publicrelations-practice/

Caulfield, Jack (September 6, 2019). How to do thematic analysis. Scribbr. Retrieved 18 November from https://www.scribbr.com/methodology/thematic-analysis/

data.bandung.go.id (2018). Dinas Kebudayaan dan Pariwisata. Jumlah Hotel Menurut Klasifikasi di Kota Bandung. Tersedia di http://data.bandung.go.id/beta/index.php/portal/detail_dataset/jumlahhotel-menurut-klasifikasi-di-kota-bandung

Dlamini, Mlandvo Africa (March 2016). Public relations Models And Corporate Social Responsibility In The Mining Sector In Richards Bay, South Africa. Thesis submitted in fulfilment of the requirements for the degree Magister Technologiae: Public relations Management in the Faculty of Informatics and Design, Cape Peninsula University of Technology

Gascon, J.F. Fondevila, E. Puiggrós, M. Muñoz, P. Mir, G. Berbel, O. Gutiérrez, L. Feliu, E. Santana, J. Rom. (2016). Use Of Social Networks For Hotel Reservations In Young People: Empirical Analysis, International Journal of Scientific Management and Tourism, Vol.2, 1, pp 55-61

Gentles, Stephen J.; Charles, Cathy; Ploeg, Jenny \& McKibbon, K, Ann (November 9, 2015). Sampling in Qualitative Research: Insights from an Overview of the Methods Literature. The Qualitative Report, 20 (11), 1772-1789. 
Grunig, James E. \& Hunt, Todd (1984). Managing Public Relations. New York: Holt, Rinehart and Winston

Gulbahar, M.Onur \& Yildirim, Fazli (2015). Marketing Efforts Related to Social Media Channels and Mobile Application Usage in Tourism: Case Study in Istanbul. Procedia - Social and Behavioral Sciences 195, $453-462$

Hudson, Matthew (23 June 2020). What Is Social Media? Definition and Examples of Social Media. Available at https://www.thebalancesmb.com/what-is-social-media-2890301

Johnson, Karen S. (2019). The Advantages of Using Facebook for Public relations. Azcentral. Available at https://yourbusiness.azcentral.com/advantages-using-Facebook-public-relations-6284.html

Joseph, Ajihson (May 24, 2017). Linkedin. Public relations Models: An Illustrative Analysis. Available at https://www.linkedin.com/pulse/public-relations-models-illustrative-analysis-dr-ajihson

Joseph, Chris (2019). Differences Between Sales and Public relations. Chron. Available at https://smallbusiness.chron.com/differences-between-sales-public-relations-24843.html

Kriyantono, Rachmat; Amrullah, Abdul Allam; dan Destrity, Nia Asthon (2017). The Model of Public relations Practices in Indonesia. Global Journal Business of Social Science Review 5 (3) $194-199$

Lee, Cheng Ean Catherine \& Low, Frannie (November 2013). Social Media and Public Relations: The perception and adoption of Facebook by Malaysian Public Relations Consultancies as effective external communication tool. Conference: Media Asia 2013: The Asian Conference on Media \& Mass Communication, November 8-10, 2013, Osaka, Japan

Mich, Luisa \& Baggio, Rodolfo (2015) Evaluating Facebook pages for small hotels: a systematic approach. Information Technology and Tourism, doi: 10.1007/s40558-015-0031-2

Nancy, Yonada (26 Juli 2019). Pengguna Facebook \& Instagram di Indonesia Terbanyak ke-4 diDunia. Available at https://tirto.id/ee8nnapoleoncat.com (2020) Facebook users in Indonesia in January 2019. Available at https://napoleoncat.com/stats/facebook-users-in-indonesia/2019/01

Pahwa, Aashish (July 2nd, 2019), Marketing Essentials. What is advertising, advertising, objectives, examples, \& importance. Available at https://www.feedough.com/what-is-advertising-advertisingobjectives-examples-importance/

reviewtrackers.com (4 November 2020). The Guide to Facebook Reviews. Available at https://www.reviewtrackers.com/blog/facebook-reviews/

Rousseau, Jesus Milton S. \& Puttaraju, K. (October 2014). SNSs \& PR Professionals: A Case Study of Facebook PR Groups as a Tool for Building Media Rapport. International Journal of Humanities and Social Science Invention (3) 10, 01-10

Seletzky, Michal and Lehman-Wilzig, Sam (2010). Factors Underlying Organizations' Successful Press Release Publication in Newspapers: Additional PR Elements for the Evolving "Press Agentry" and "Public Information" Models. International Journal of Strategic Communication, 4: 244-266. DOI: 10.1080/1553118X. 2010.515538

Simpson, Ebony (June 11, 2014). Linkedin. The Four Models in Grunig's and Hunt's PR Theories. Available at https://www.linkedin.com/pulse/20140611205435-83891954-the-four-models-ingrunig-s-and-hunt-s-pr-theories

Surbhi S (July 29, 2017). Difference Between Advertising and Public relations. Key Differences. Available at https://keydifferences.com/difference-between-advertising-and-public-relations.html

Tewes, Ryan A. (Spring 2016). Two-Way Symmetrical Communication and Twitter in Professional Sports Public relations. A Thesis Presented to the Faculty of San Diego State University

Tjepkema, Lindsay (2019). Emarsys. Top 5 Social Media Predictions for 2019 available at https://www.emarsys.com/resources/blog/top-5-social-media-predictions-2019/.

Turney, Michael (2017). Further perspective on the mutual satisfaction phase of public relations: Asymmetric v. Symmetric public relations. Available at http://www.practicingpublicrelations.com/readings/3eras3x.html

ukessays.com (2019). The Press Agentry Model Media Essay. Retrieved 17 November 2019 from https://www.ukessays.com/essays/media/the-press-agentry-model- media-essay.php

Vaughan, Jaime Rae (23 November 2019) Social Networking for Public relations. Available at https://jrvaugha.wordpress.com/2010/11/23/social-networking-for-public-relations/

World Population Review (11 Juli 2019). Indonesia Population 2019. Available at $\mathrm{http} / / /$ worldpopulationreview.com/countries/indonesia-population/ 
Zeng B \& Gerritsen R (2014) What do we know about social media in tourism? A review. J Tourism Management Perspectives. doi: 10.1016/j.tmp.2014.01.001

*Email korespondensi:

Santosa Sanjaya

santosasanjaya@gmail.com 